\title{
Validating the Measurement of Maqasid Syariah Prison Quality of Life (MSPQoL) among Drug- Abuse Inmates
}

\author{
[Mahadzirah Mohamad, NorAzman Mat Ali, Zainuddin Awang, Nizaita Omar \\ and Harmy Mohamed Yusoff]
}

\begin{abstract}
The purpose of this study is to validate the proposed measurement model of Maqasid Syariah Prison quality of life (MSPQoL) among drug abusers required to serve prison sentences in Malaysia. The Maqașid Syariah approach of measuring quality of life postulates that safeguarding people's well-being would be achieved through protecting the people's five life- related elements, namely "Religion", "Life", "Mind", "Lineage" and "Property". The specific objective of the study is to ascertain reliable and valid items manifesting the dimensions of MSPQoL. The study was conducted at the three prisons located in the east coast of Peninsular Malaysia. A total of 248 respondents were involved in the study. Respondents were asked to give their responses to the given statements based on their level of agreement or disagreement using self-administered questionnaires guided by trained enumerators. The measurement model of the latent constructs was validated through Confirmatory Factor Analysis (CFA) procedure in IBM-SPSS_AMOS 21.0. CFA was applied to assess the uni-dimensionality, validity, and reliability of the latent constructs using several statistical measures such as construct validity, convergent validity, discriminant validity, and composite reliability. The findings of the study suggested that MSPQoL was established by five constructs namely, "Religion", "Life", "Mind', "Lineage" and "Property", supporting the proposed hypothesis. "Religion, "Life", "Lineage" and "Property" consisted of three underlying components and were measured by eleven, ten, twelve and nine observable items respectively. "Mind" was measured by two underlying constructs manifested by ten observable items. The findings of the study would provide an alternative reliable and validated measurement of prison quality of life based on the perceptions of the individuals, especially among the drug abuse inmates. Using MSPQoL, the prison healthcare management could identify aspects of quality of life that require improvements and plan appropriate policies and strategies to enhance drug-abuse inmates' quality of life.
\end{abstract}

Keywords - prison quality of life, drug-abuse inmate, Maqasid Syariah, measurement model, Malaysia

\section{Introduction}

The discussion on quality of life generally focused on an individual's system of living within a community from being an unsatisfactory or less a satisfactory state to a satisfactory or more satisfactory state. Quality of life is an important concept because it is used by different parties for

Mahadzirah Mohamad, Nor Azman Mat Ali, Zainudin Awang, Nizaita Omar and Harmy Mohamed

Universiti Sultan Zainal Abidin

Malaysia development status, along with its economic growth and political stability. Usually, the emphasis is to achieve the nation's economic growth accompanied with a parallel growth in the people's quality of life. In the case of drugabuse inmates, quality of life could be used as an instrument to assess aspects that could be improved by the prison healthcare management to promote drug-abuse inmates' life satisfaction. Many perceive that life in prison would be as described in most television dramas or movies - poor living conditions with bad treatment from cruel warden, fighting among inmates in the cells with inmates being confined to eight by ten feet cells. However, there is actually humane life in prison, whereby some prison institutions create a sense of being for the inmates to give them a second chance to live their lives upon finishing their term of punishment in the prison. This is the approach adopted by the Malaysia prisons that transformed the imprisonment of inmates from a penitentiary to a correctional and rehabilitation approach. An inmate rehabilitation approach was embarked upon by the Malaysia prisons institution through various methods to improve their prison quality of life, such as face-to-face family meetings, self-development programmes, and early release for rehabilitated inmates through the parole system [1].

It was reported by the Ministry of Home Affairs that 45 - 50 per cent of imprisoned inmates were involved with drugabuse [2]. Hence, adequate attention should be given to identify the suitable tool measuring prison quality of life among drug-abuse inmates to address the quality of life development required of this group. It was noted by Laudet [3] that understanding inmates' prison quality of life is an important element in the rehabilitation process. Moreover, identifying inmates' quality of life is necessary to the development of specific prevention, care strategies, and appropriate policies for this subgroup [4] to improve their quality of life during the period of imprisonment. Acknowledging the fact that "one size does not fit all", as different groups of individual have different requirements, assessment on prison quality of life among drug-abuse inmates should be done thoroughly to help the relevant parties in drafting suitable policies and in constructing coping strategic plans to accommodate the needs of this subgroup. Inappropriate tool would provide incorrect information leading to inaccurate, ineffective and inefficient solutions to rehabilitate drug-abuse inmates. This, in turn, would not help the prison institution authorities to identify aspects of prison quality of life that should be given more 
attention in order to improve the drug-abuse inmates prison quality of life.

The definition of quality of life is "multidimensional" and uses multiple approaches and instruments [5] meeting the particular need of the respective research endeavours. Moreover, the definition of quality of life has been interpreted by various parties according to their field of study. For example, Brown and Brown [6] defined quality of life as achieving a good life, success and happiness of living in a surrounding. This opinion supports the view by Liu [7] which states that the quality of life consists of a set of individual's needs to several aspects of life, and when this combination of needs is fulfilled simultaneously, it gives the individual a sense of happiness and satisfaction. Quality of life can also be described as an individual's or a society's state of prosperity. This definition was in line with Moriarty [8] who stated that the quality of life is a feeling of prosperity of people who are living in a surrounding that fosters them to achieve prosper in a society. The Malaysian Quality of Life [9] defines quality of life as encompassing personal advancement, healthy lifestyle, access and freedom to pursue knowledge and attaining a standard of living which surpasses the fulfilment of the basic and psychological needs of an individual to achieve a level of social well-being.

Therefore, this study was conducted to measure drug-abuse inmate prison quality of life using the Maqasid syariah approach (MSPQoL). The MSPQoL approach of measuring quality of life postulates that safeguarding people's wellbeing or quality of life would be achieved through protecting the people's five life related elements, namely "Religion", "Life", "Mind", "Lineage" and "Property". The development of prison MSPQoL among drug inmates provides an alternative complementary measurement of quality of life developed by previous studies. Measuring the quality of life using Maslow's Hierarchy of Needs requires improvement because the approach focused on assessing the needs and wants aspects without taking into consideration the aspects of justice, spiritual and public interest [10]. Therefore, in order to fill the gap, the Maqasid Syariah approach of measuring quality of life was proposed in this study.

\section{The Concept of Quality of Life based on Maqasid Syariah Approach}

The underlying fundamental value and objective of Maqasid Syariah is the awareness to safeguard the public interest [11] by safeguarding people's well-being through protecting the five elements related to people's life, namely religion, life, mind, lineage and property. The act of protecting these elements was to ensure the welfare, public interests and justice within the community and society were maintained [11]. Abraham Maslow proposed the theory on quality of life according to human development perspective, emphasizing human satisfaction on several needs, known as the 'Hierarchy of Needs'. In general, Maslow's Hierarchy of
Needs is divided into five stages, namely the physiological, safety, love, self- esteem, and self- actualization needs which became the basis for development of quality of life measurements. Based on Maslow's Hierarchy of Needs, Hornquist [12] defined quality of life from basic human needs and the ability to fulfill human satisfaction derived from these needs. It was noted that fulfilling the satisfaction of human needs as the basis for the measurement of quality of life appeared to be addressing fulfilling material needs without limit. In contrast, the Maqasid Syariah approach which holistically measures quality of life, based on the five dimensions, namely protection of religion, life, mind, lineage and property, was observed to be addressing both material and spiritual needs, in addition to addressing public justice. Moreover, Maqasid Syariah is the essence of human life which if failed to be adequately addressed would lead to chaos and uncertainty in life [13].

\section{Method}

Self-administered survey questionnaires were distributed by trained enumerators among drug-abuse inmates sentenced to imprisonment in the three prisons located in the east coast of Peninsular Malaysia. The respondents were selected using a simple random-sampling approach from a sampling frame provided by the prison authority. A total of 248 respondents were involved in the study. Respondents were asked to indicate the extent of their agreement or disagreement to the items measuring MSPQoL using a measurement scale ranging from 1 (strongly disagree) to 10 (strongly agree).

The research instrument contained items developed to manifest the five dimensions of MSPQoL namely religion, life, mind, lineage and property. Items to measure each dimension were generated based on literatures and expert panel interviews. Literatures suggested that the dimension of religion was measured by three underlying factors identified as Islam, Iman and Ihsan. The dimension of life was measured by three underlying factors labelled as Basic Needs, Recreation and Sport; and Safety. The dimension of mind was measured by two underlying factors labelled as Attitude and Character. Lineage was measured by three underlying factors labelled as Friendship, Law Enforcement and Family Relationships. Lastly, the dimension of Property was measured by three underlying factors recognized as Management, Production and Distribution.

The measurement model of the latent constructs was validated through Confirmatory Factor Analysis (CFA) procedure in IBM-SPSS_AMOS 21.0. CFA was applied to assess the uni-dimensionality, validity, and reliability of the latent constructs using several statistical measures such as construct validity, convergent validity, discriminant validity, and composite reliability. 


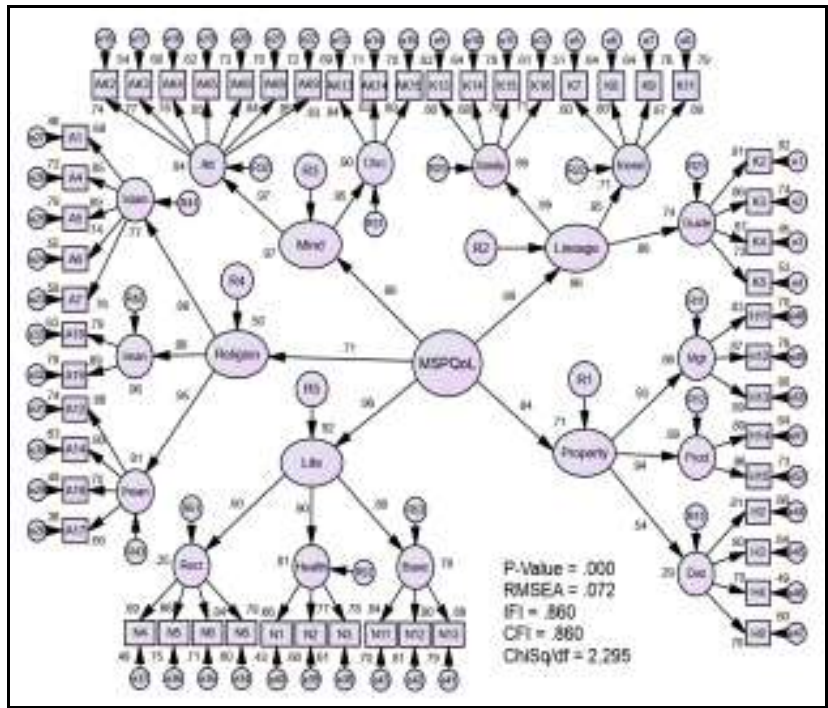

Fig.1. The Third-order Model of MSPQoL

\section{Results}

The respondents involved in the study were Muslim Malay male drug-abuse inmates. Most of them were sentenced to a punishment of one year or less. The majority of the respondents $(83 \%)$ were youths in the productive age group of 21-35 years old and $92 \%$ of them had finished high school, with highest education at Sijil Pelajaran Malaysia level. Most of the respondents (72\%) were self-employed (doing odd-jobs) and earning an average income of less than RM1,000 per month (49\%). Majority of them were single $(59 \%)$ and they indicated that the first time they got involved in drug-abuse incidents were when they were between the ages of 15 to 20 years old. The first three main reasons why they became involved in drug-abuse were because of curiosity, followed by the influence of friends and to have fun. The percentages of the respondent imprisoned on cases related to drug abuse for the first, second and third time were 32, 27 and 13 per cent respectively.

The findings of the study suggested a third-order measurement model of MSPQoL consisting of five secondorder models namely, "Religion", "Life", "Mind", "Lineage" and "Property" as illustrated in Fig. 1. The Fitness Indexes, incremental fit index (IFI), comparative fit index (CFI), root mean square error of approximation (RMSEA) and normed ChiSquare, achieved the required level of acceptance indicating the model met construct validity. The values of composite reliability (CR) equals to 0.96 , exceeding 0.6 , and average variance extracted (AVE) equals to 0.81 , exceeding 0.5 , for the first order MSPQoL model achieved the required level of acceptance indicating that the model achieves the requirements for composite reliability and convergent validity.

In addition, the values of CR and AVE of the second-order model for every construct achieved the level of acceptance; Religion $(\mathrm{CR}=0.96, \quad \mathrm{AVE}=0.88)$ Life $\quad(\mathrm{CR}=0.82$, $\mathrm{AVE}=0.61), \quad$ Mind $\quad(\mathrm{CR}=0.96, \quad \mathrm{AVE}=0.92), \quad$ Lineage $(\mathrm{CR}=0.93, \mathrm{AVE}=0.81)$ and Property $(\mathrm{CR}=0.86, \mathrm{AVE}=0.68)$,

meeting the composite reliability and convergent validity requirements. Similarly, the first-order model of MSPQoL achieved the composite reliability and convergent validity requirement as illustrated in Table I. Table II illustrates items measuring MSPQoL's sub-constructs namely, Religion (Islam, Iman, Ihsan), Life (Sport and Recreation, Health, Basic Needs), Mind (Attitude, Characteristics), Lineage (Family, Friends, Guideline) and Property (Management, Production, Distribution).

\section{v. Conclusion}

The findings of the study provide an alternative reliable and validated measurement of prison quality of life based on the perceptions of the individuals especially among the drug-abuse inmates. Using MSPQoL, the prison healthcare management could understand and identify aspects of quality of life (religion, life, mind, lineage and property) that would require improvements. The prison authority could develop specific prevention, care strategies, and appropriate policies to enhance drug-abuse inmates' quality of life during their period of imprisonment. This is in course with transforming the Malaysia prisons imprisonment of inmates approach from a penitentiary to a correctional and rehabilitation approach.

TABLE I. THE CR AND AVE FOR ALL FIRST ORDER CONSTRUCTS OF MSPQOL

\begin{tabular}{|c|c|c|}
\hline Construct/Sub construct & $C R$ & $\boldsymbol{A V E}$ \\
\hline \multicolumn{3}{|l|}{ Religion } \\
\hline Islam & 0.89 & 0.62 \\
\hline Iman & 0.83 & 0.71 \\
\hline Ihsan & 0.83 & 0.56 \\
\hline \multicolumn{3}{|l|}{ Life } \\
\hline Sport and recreation (Recr) & 0.87 & 0.63 \\
\hline Health & 0.78 & 055 \\
\hline Basic needs (Basic) & 0.91 & 0.77 \\
\hline \multicolumn{3}{|l|}{ Mind } \\
\hline Attitude (Att) & 0.93 & 0.66 \\
\hline Characteristic (Chrc) & 0.86 & 0.68 \\
\hline \multicolumn{3}{|l|}{ Lineage } \\
\hline Family & 0.87 & 0.63 \\
\hline Friend & 0.91 & 0.71 \\
\hline Guideline (Guide) & 0.87 & 0.64 \\
\hline \multicolumn{3}{|l|}{ Property } \\
\hline Management (Mgt) & 0.90 & 0.75 \\
\hline Production (Prod) & 0.82 & 0.69 \\
\hline Distribution (Dist) & 0.86 & 0.60 \\
\hline
\end{tabular}


Proc. of the Fourth Intl. Conf. Advances in Social Science, Economics and Management Study- SEM 2016

Copyright (C) Institute of Research Engineers and Doctors, USA .All rights reserved.

ISBN: 978-1-63248-094-1 doi: 10.15224/ 978-1-63248-094-1-55

TABLE II. ITEMS MEASURING MSPQOL

\begin{tabular}{|c|c|}
\hline $\begin{array}{c}\text { Construct/Sub } \\
\text { construct }\end{array}$ & Item \\
\hline \multicolumn{2}{|l|}{ Religion } \\
\hline \multirow[t]{5}{*}{ Islam } & I read the Holy Quran everyday (A1) \\
\hline & I perform the five daily obligatory prayers (A4) \\
\hline & $\begin{array}{l}\text { I always perform the optional voluntary prayers } \\
\text { (A5) }\end{array}$ \\
\hline & I fast for a full month during Ramadan (A6) \\
\hline & I perform the optional fasting regularly (A7) \\
\hline \multirow[t]{2}{*}{ Iman } & I love Prophet Muhammad SAW (A18) \\
\hline & $\begin{array}{l}\text { I believe in the existence of the Day of Judgement } \\
\text { (A19) }\end{array}$ \\
\hline \multirow[t]{4}{*}{ Ihsan } & I refrain from hurting others (A12) \\
\hline & I smile when I deal with others (A14) \\
\hline & I forgive others for their wrongdoings (A16) \\
\hline & I will admit my mistakes (A17) \\
\hline \multicolumn{2}{|l|}{ Life } \\
\hline \multirow[t]{3}{*}{$\begin{array}{l}\text { Sport and } \\
\text { recreation } \\
\text { (Recr) }\end{array}$} & $\begin{array}{l}\text { I am actively participating in recreation } \\
\text { programmes.(N4) }\end{array}$ \\
\hline & I exercise to keep fit (N5) \\
\hline & I fill my free time with exercising (N6) \\
\hline \multirow[t]{3}{*}{ Health } & $\begin{array}{l}\text { I practice the sunnah dietary habits as a form of } \\
\text { medicinal treatment (e.g: honey,black cummin and } \\
\text { zam-zam water) (N1) }\end{array}$ \\
\hline & $\begin{array}{l}\text { I practice the readings of the verses from the Holy } \\
\text { Quran for health.(N2) }\end{array}$ \\
\hline & $\begin{array}{l}\text { I practice the readings of the verses from the Holy } \\
\text { Quran for safety (N3) }\end{array}$ \\
\hline \multirow[t]{3}{*}{$\begin{array}{l}\text { Basic needs } \\
\text { (Basic) }\end{array}$} & The food that my family consume is halal (N11) \\
\hline & Clean food is my priority (N12) \\
\hline & Safe food is my priority (N13) \\
\hline \multicolumn{2}{|l|}{ Mind } \\
\hline \multirow[t]{7}{*}{ Attitude (Att) } & $\begin{array}{l}\text { I practice time management so that I will not be } \\
\text { stressed (AK2) }\end{array}$ \\
\hline & $\begin{array}{l}\text { I give admonition to those committing bad deeds } \\
\text { (AK3) }\end{array}$ \\
\hline & $\begin{array}{l}\text { I share my views regarding everyday life to others } \\
\text { (AK4 }\end{array}$ \\
\hline & I respect the views of others (AK5) \\
\hline & $\begin{array}{l}\text { I am careful in making decision so as to not break } \\
\text { the commandment of Allah SWT (AK6) }\end{array}$ \\
\hline & $\begin{array}{l}\text { I contribute my views in discussion regarding } \\
\text { matters of everyday life (AK8) }\end{array}$ \\
\hline & $\begin{array}{l}\text { I strive to complete my tasks within the allocated } \\
\text { time (AK9) }\end{array}$ \\
\hline \multirow[t]{3}{*}{$\begin{array}{l}\text { Characteristic } \\
\text { (Chrc) }\end{array}$} & $\begin{array}{l}\text { Seeking knowledge that does not contradict with } \\
\text { the shariah can draw oneself closer to Allah } \\
\text { SWT(AK13) }\end{array}$ \\
\hline & $\begin{array}{l}\text { Seeking knowledge that does not contradict with } \\
\text { the shariah is a form of worship (AK14) }\end{array}$ \\
\hline & Seeking knowledge is a lifelong effort (AK15) \\
\hline \multicolumn{2}{|l|}{ Lineage } \\
\hline \multirow[t]{3}{*}{ Family } & $\begin{array}{l}\text { Loyalty is very important in a relationship between } \\
\text { husband and wife (K13) }\end{array}$ \\
\hline & $\begin{array}{l}\text { Not paying attention to the family will affect the } \\
\text { relationship between family members (K14) }\end{array}$ \\
\hline & $\begin{array}{l}\text { Not respecting partner will affect the relationship } \\
\text { between husband and wife( K15) }\end{array}$ \\
\hline
\end{tabular}

\begin{tabular}{|l|l|}
\hline $\begin{array}{c}\text { Construct/Sub } \\
\text { construct }\end{array}$ & \multicolumn{1}{c|}{ Item } \\
\hline & $\begin{array}{l}\text { It is forbidden for unmarried couple to be alone in a } \\
\text { secluded place (K16) }\end{array}$ \\
\hline Friend & $\begin{array}{l}\text { I pray for the well-being of my parents everyday } \\
\text { (K7) }\end{array}$ \\
\hline & My friends help me when I am in need (K8) \\
\hline $\begin{array}{l}\text { Guideline } \\
\text { IGuide) }\end{array}$ & I protect my friends' dignity (K9) \\
\hline & $\begin{array}{l}\text { I choose my life partner because of her religion } \\
\text { (K3) }\end{array}$ \\
\hline $\begin{array}{l}\text { Marriage can strengthen the relationship between } \\
\text { families (K4) }\end{array}$ \\
\hline $\begin{array}{l}\text { Production } \\
\text { (Prod) }\end{array}$ & I fulfill my responsibilities as husband/wife (K5) \\
\hline $\begin{array}{l}\text { Management } \\
\text { (Mgt) }\end{array}$ & $\begin{array}{l}\text { I set aside a portion of my money for charitable } \\
\text { causes (H11) }\end{array}$ \\
\hline & $\begin{array}{l}\text { I make personal budget (H12) } \\
\text { can avoid disputes among heirs (H8) }\end{array}$ \\
\hline & I make personal financial planning (H13) \\
\hline Saving money legally (H14) \\
\hline & Savings can ensure life prosperity (H3) \\
\hline & Savings can generate profit (H4) \\
\hline
\end{tabular}

\section{Acknowledgment}

This study was funded by the Ministry of Higher Education, Malaysia. The authors would like to thank the Malaysia Prison Department for giving the support and permission to conduct at the study at the selected prisons.

\section{References}

[1] "Eleventh Malaysia Plan 2016-2020 Anchoring Growth on People", Percetakan Nasional Malaysia Berhad., Putrajaya, 2015.

[2] Kosmo, "50 peratus banduan penagih dadah", 2014.

[3] A. Laudet, "The case for considering quality of life in addiction research and clinical practice", Addiction Science \& Clinical Practice, pp. 44-55, 2011.

[4] G. J. Dore, Health-Related Quality of Life in Prisoners. New York: Springer, 2010, pp. 3413-3423.

[5] L. Abdullah, "Validation of an Instrument for Measuring Quality of Life amongst Malaysian Youth", Modern Applied Science, vol. 8, no. 2, 2014.

[6] R. Brown and I. Brown, "The application of quality of life", Journal of Intellectual Disability Research, vol. 49, no. 10, pp. 718-727, 2005.

[7] B. Liu, Quality of Life Indicators on U.S. Metropolitan Areas : A Statistical Analysis. , Edition of book, New York.: Praeger Publishers, 1976, p. .

[8] D. Moriarty, "CDC Studies Community Quality of Life", NACCHO News, vol. 12, no. 3, pp. 10-13, 1996

[9] [9] "Malaysian Quality of Life 2011", Economic Planning Unit, Putrajaya, 2011

[10] D. Abdul Razak, S. Ab. Hamid and S. Ya'kob, "Needs and Wants Theory: A comparison between Maslow's Hierarchy of Needs and 
Proc. of the Fourth Intl. Conf. Advances in Social Science, Economics and Management Study- SEM 2016

Copyright (c) Institute of Research Engineers and Doctors, USA .All rights reserved.

ISBN: 978-1-63248-094-1 doi: 10.15224/ 978-1-63248-094-1-55

Maqasid al Shariah", in 10th Asian Academy of Management, Penang, Malaysia, 2013.

[11] N. Abdul Aris, R. Mohd Azli and R. Othman, "Maqasid Shariah in Islamic Finance: Assessment on Ideologies of Muslim Philosophers and Economists", in Proceeding of the Islamic Economics System Conference 5, 2013, pp. 427-440.

[12] J. Hornquist, " The Concept of Quality of Life," Scandinavian Journal of Social Medicine, Vol. 10, no. , 57-61., 1982.

[13] M. Mohammad and S. Shahwan, "The objective of Islamic economic and Islamic banking in light of Maqasid Al-Shariah: A critical review", Middle-East Journal of Scientific Research (Research in Contemporary Islamic Finance and Wealth Management, no. 13, pp. 75-84, 2013

About Author:

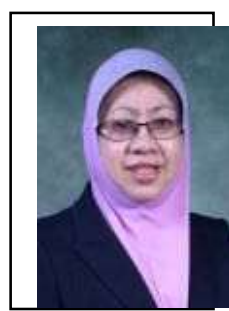

Mahadzirah Mohamad is a Professor of Marketing at the Universiti Sultan Zainal Abidin (UniSZA). Upon completing her secondary education, she entered Universiti Teknologi MARA (UiTM) and graduated in Business Studies in July 1981. She obtained a Degree in Bachelor of Business Administration (Summa Cum Laude) from the Ohio University, USA in 1984. She continued her studies at the Universiti Kebangsaan Malaysia (UKM) and obtained a Master of Business Administration (MBA) in 1989. Subsequently, she pursued her studies to a higher level in the field of services marketing and received her $\mathrm{PhD}$ in 1998 from the Exeter University, UK. 